\title{
SISTIM PERTANIAN TERPADU PETERNAKAN KAMBING DENGAN LIMBAH HASIL PRODUKSI KOPI DI DESA TRIBUDISYUKUR LAMPUNG BARAT
}

\author{
A. Analianasari ${ }^{1^{*}}$, Dayang Berliana ${ }^{2}$, Meinilwita Yulia ${ }^{3}$, Eko Win Kenali ${ }^{4}$ \\ ${ }^{1}$ Pengembangan Produk Agroindustri/Jurusan Teknologi, Politeknik Negeri Lampung, \\ Email:analianasari@polinela.ac.id \\ ${ }^{2}$ Agribisnis Pangan/Jurusan Ekonomi dan Bisnis, Politeknik Negeri Lampung, \\ Email: dayang@polinela.ac.id \\ ${ }^{3}$ Mekanisasi Pertanian/Jurusan Teknologi, Politeknik Negeri Lampung \\ Email: meinilwitayulia@polinela.ac.id \\ ${ }^{4}$ Manajemen Informatika Komputer/Jurusan Ekonomi dan Bisnis Politeknik Negeri Lampung \\ Email: ekowins07@polinela.ac.id
}

\begin{abstract}
Coffee husk waste has not been used optimally from the by-product of coffee bean processing production (green bean) and there is no integrated farming system between agriculture and animal husbandry. The purpose of the PPPUD service is to utilize coffee skin waste as animal feed, (2) to design healthy goat cages to optimize livestock manure waste. The implementation method is the extension and demonstration method with the stages of initial implementation, implementation of activities, and final implementation. The result of the activity is the transfer of innovation in animal feed processing training by utilizing coffee skin waste and other fiber materials, as well as the concept of a goat drum with a waste disposal site that can be used for processing waste into compost so as to increase income.
\end{abstract}

Keywords: Integrated farming system, coffee husk waste, animal feed

\begin{abstract}
ABSTRAK
Limbah kulit kopi belum dimanfaatkan secara optimal dari hasil samping produksi pengolahan biji kopi (green bean) dan belum adanya sistim pertanian terpadu antara pertanian dan peternakan. Tujuan dari pengabdian PPPUD memanfaatkan limbah kulit kopi menjadi pakan ternak, (2) mendesain kandang kambing sehat untuk mengotpimalkan limbah kotoran ternak. Metode pelakasanaan dengan metode penyuluhan dan demontrasi cara dengan tahapan pelaksanaan awal, Pelaksanaan keiatan, dan Pelaksanaan akhir. Hasil deari kegiatan adalah transfer inovasi pelatihan pengolahan pakan ternak dengan memanfaatkan limbah kulit kopi dan bahan serat lainnya, serta konsep kendang kambing dengan tempat pembuangan limbah dapat dimanfaatkan untuk pengolahan limbah menjadi pupuk kompos sehingga meningkatkan pendapatan.
\end{abstract}

Kata kunci: Sistim pertanian terpadu, limbah kulit kopi, pakan ternak

\section{PENDAHULUAN}

Sistem pertanian terpadu adalah kegiatan yang dilakukan dengan mengintegrasikan satu atau dua kegiatan pertanian dalam satu wilayah. Kegiatan yang dapat dintegrasikan adalah pertanian dan peternakan, peternakan dengan sisa produksi (limbah) dari produksi kopi. Penerapan sistim pertanian terpadu pada hasil limbah pengolahan kopi merupakan salah satu usaha untuk memanfaatkan limbah menjadi produk yang menguntungkan, pola ini menjadi pengelolaan tanpa limbah (zero waste) (Hadija et al., 2016). Saragih, (2020) menambahkan bahwa pola penerapan integrasi sistem pertanian terpadu antara sektor pertanian dan peternakan dapat meningkatkan pendapatan masyarakat.

Desa Tribudisyukur merupakan salah satu desa di Kecamatan Kebun Tebu yang memiliki lahan kopi dengan produktivitas $900 \mathrm{~kg} / \mathrm{Ha}$. Biji kopi yang dihasilkan adalah biji kopi asalan dan biji kopi premium. Pengolahan biji kopi premium telah dilaksanakan oleh masyarakat desa Tribudisyukur yang dikelola secara berkelompok oleh Gapoktan Triguna sejak Tahun 2017. Biji kopi premium merupakan biji kopi yang dihasilkan dari buah kopi cery merah sehingga 
memiliki harga jual yang tinggi berkisar antara Rp $35.000-45.000 / \mathrm{kg}$. Permintaan biji kopi premium meningkat seiring dengan tren minum kopi di kedai kopi Bandar Lampung. Analianasari et al., (2021) menyatakan bahwa biji kopi premium dihasilkan dari proses kering (dry process) Natural, Honey dan proses basah (Full Wash). Namun, permintaan biji kopi dengan proses kering lebih tinggi dibandingkan dengan proses basah.

Biji kopi proses pengolahan kering menghasilkan limbah kulit kopi berkisar antara 35-40\%. Jika produksi buah kopi merah sebanyak $900 \mathrm{~kg} / \mathrm{Ha}$, maka akan menghasilkan limbah sebanyak \pm 315-405 kg. Potensi limbah ini dapat dimanfaatkan menjadi sumber pakan bagi peternakan kambing lokal. Berdasarkan wawancara dengan anggota gapoktan limbah kopi hanya dimanfaatkan sebagai pupuk kompos atau hanya dibuang saja tanpa pemanfaatan secara optimal. Efendi \& Harta, (2013) menyatakan bahwa kulit kopi dapat diolah sebagai pakan karena kulit kopi mempunyai kecernaan protein sebesar 65\%. Linda et al., (2018) menambahkan bahwa dialam kulit kopi mengandung protein $8,549 \%$ lebih tinggi dibandingkan dengan kandungan zat nutrisi rumput.

Potensi yang tinggi dari kulit limbah yang dihasilkan dari produksi pengolahan kopi Gapoktan Triguna dan masyarakat disana banyak yang memiliki peternakan kambing local yang disebut kambing kacang. Integrasi sistim pertanian terpadu antara peternakan kambing yang dikelola dengan baik dengan hasil limbah dari pengolahan kopi biji (green bean) dapat meningkatkan pendapatan dan meminimalkan biaya pengeluaran pakan dan pembelian pupuk.

Berdasarkan pengamatan di lapangan kandang kambing yang ada masih bersifat konvensional sehingga dalam mengumpulkan limbah kotoran kambing dan urin masih dilakukan dengan sederhana, yaitu menggunakan cangkul. Konsep kandang dengan konsep kandang sehat dapat memudahkan petani dalam mengumpulkan kotoran dan urin ternak yang selanjutnya dapat diproses menjadi pupuk kompos dan dikembalikan pada kebun kopi.

Program pengabdian berupaya untuk mengoptimalkan pengelolaan limbah kulit kopi sebagai pakan ternak melalui teknologi fermentasi. Tujuan kegiatan ini adalah (1) memanfaatkan limbah kulit kopi menjadi pakan ternak, (2) mendesain kandang kambing sehat untuk mengotimalkan limbah kotoran ternak.

\section{METODE PELAKSANAAN PKM}

PelaksanaanProgram Pengembangan Produk Unggulan Daerah (PPPUD) dilaksanakan dari bulan April - September 2021 di Gapoktan Triguna desa Tribudisyukur Kecamatan Kebun Tebu Lampung Barat. Metode pelaksanaan menggunakan metode penyuluhan dan Demontrasi cara. Penyuluhan yang diberikan adalah konsep kandang sehat dan proses pengolahan limbah kulit kopi menjadi pakan ternak dengan teknologi fermentasi, sedangkan demontrasi yang dilaksanakan adalah proses pembuatan pakan ternak dari limbah kulit kopi dengan proses fermentasi. Mekanisme pelaksanaan terdiri dari tahapan: Sosialisasi kegiatan, Pelaksanaan Kegiatan, dan Evaluasi kegiatan akhir.

\section{HASIL DAN PEMBAHASAN}

Sosialisasi kegiatan. Pelaksanaan sosialisasi kegiatan dilaksanakan pada tanggal 24 April 2021. Kegiatan dilakukan dengan 2 kali kunjungan, kunjungan pertama adalah sosialisai yang disampaikan oleh ketua Tim PPPUD Analianasai, S.T.P., M.T.A, dengan materi pemanfaatan limbah kulit kopi. Kegiatan sosialiasi dihadiri oleh pebisnis perkopian di Bandar Lampung dengan konsep kopi 'Sehat", yaitu Bapak Komar pemilik kedai kopi "Warkop WAW". Beliau menyampaikan materi tentang manfaat yang tinggi dengan melakukan pasca panen kopi petik merah sehingga limbah yang dihasilkan memiliki kandungan nutrisi yang tinggi, terutama kandungan antioksidan (Gambar 1). 


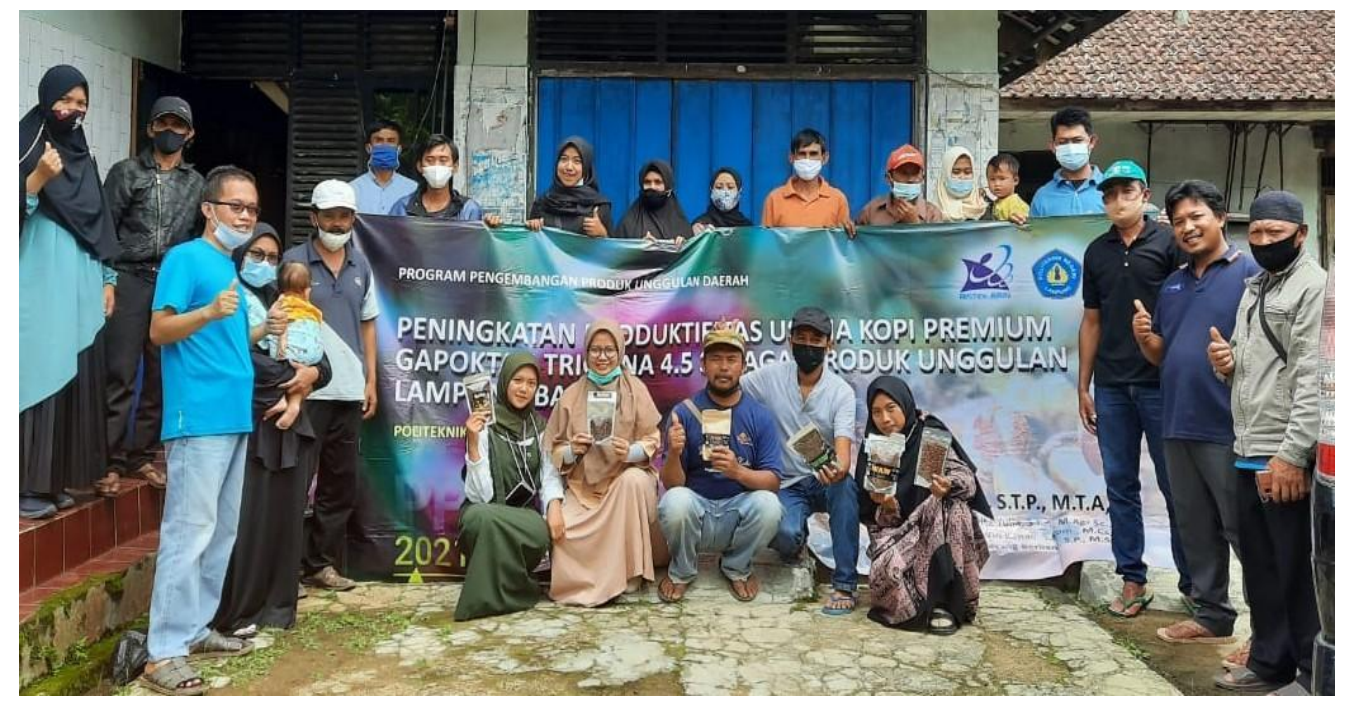

\section{Gambar 1}

Sosialisasi kegiatan program pengembangan produk unggulan daerah pada kunjungan pertama tanggal 24 April 2021

Kunjungan kedua dilaksanakan pada Tanggal 11 September 2021 bersama Tim PPPUD dan narasumber Pengolahan limbah kulit kopi menjadi pakan ternak disampaikan oleh Agung Adi Candra, S.Kh., M.Si selaku Dosen Peternakan Politeknik Negeri Lampung. Kegiatan dihadiiri oleh 15 orang petani sekaligus pemilik ternak kambing.

Pelaksanaan kegiatan. Pelaksanaan kegiatan diawali dengan penyuluhan yang disampaikan oleh Bapak Agung Adi Candra, SKh, M.Si,bahwa limbah kulit kopi memiliki potensi dapat diolah menjadi pakan ternak. Limbah kulit kopi mengandung nutrient protein kasar $5,81 \%$, serat kasar 24,20\%, lemak 1,07\%, Ca 0,23\%, P 0,02\%, dan BETN 22,4\%. Proses pembuatan pakan diawalii dengan membuat inoculum/biang/bibit starter dengan menggunakan dedak padi, kulit buah kopi, air gula dan Starter EM4 peternakan. Pembuatan starter inoculum mikroba bertujuan untuk mengedukasi petani bahwa starter dapat dibuat secara mandiri dengan memanfaatkan limbah kulit kopi dan bahan tambahan lainnya yaitu dedak padi, larutan gula dan EM4. Dekomposer EM4 yang mengandung mikroba pengurai selulosa untuk menguraikan kandungan serat yang terdapat pada kulit kopi dan bahan lainnya (rumput gajah dan dedak padi).

Rumput gajah sebelum dicampurkan dilakukan proses pengecilan ukuran dengan tujuan untuk mempercepat proses penguraian. Pengecilan ukuran dilakukan dengan memasukkan rumput kedalam mesin pencacah. Rumput gajah selanjutnya dicampurkan kedalam kantong plastic besar dengan bahan baku yang sudah ditambahkan EM4, kulit kopi, dedak, dan larutan gula dan difermentasi selama 3 minggu. EM 4 (effective microorganism) sebagai bahan pembantu proses fermentasi. Pengolahan dengan menggunakan teknologi fermentasi dapat meningkatkan kandungan protein terutama untuk beberapa limbah berserat termasuk daging buah kopi. Proses fermentasi dengan inoculum Aspergilus niger, kadar protein daging buah kopi dapat ditingkatkan dari $9,8 \%$ menjadi $12,43 \%$ (S et al., 2002). Proses pengolahan pakan ternak dari limbah kulit kopi diuraikan pada diagram alir Gambar 2. 


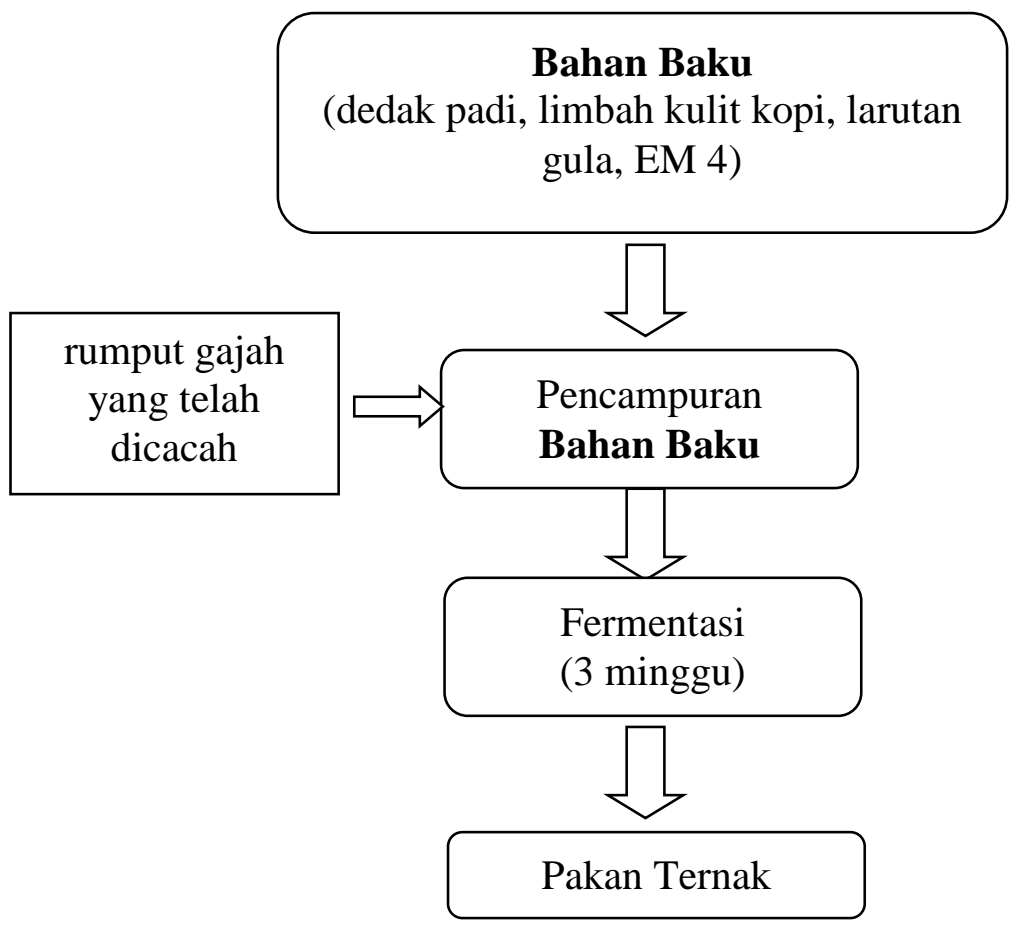

\section{Gambar 2}

Diagram alir proses pengolahan kulit kopi menjadi pakan ternak

Pada tahap pelaksanaan dilakukan serah terima mesin pencacah yang berguna untuk mengecilkan ukuran dari bahan-bahan yang mengandung serat untuk mempercepat proses fermentasi (Gambar 3). Menurut Winarso \& Basuno, (2013) untuk keberhasilan pendampingan pada kelompok untuk integrasi budidaya kopi maupun peternakan diperlukan beberapa upaya yaitu (a) pembinaan intensif untuk bimbingan teknis (pakan, reproduksi, perkandangan, dan pemeliharaan), (b) pengadaan bantuan peralatan pengolahan limbah terutama alat pencacah rumput.

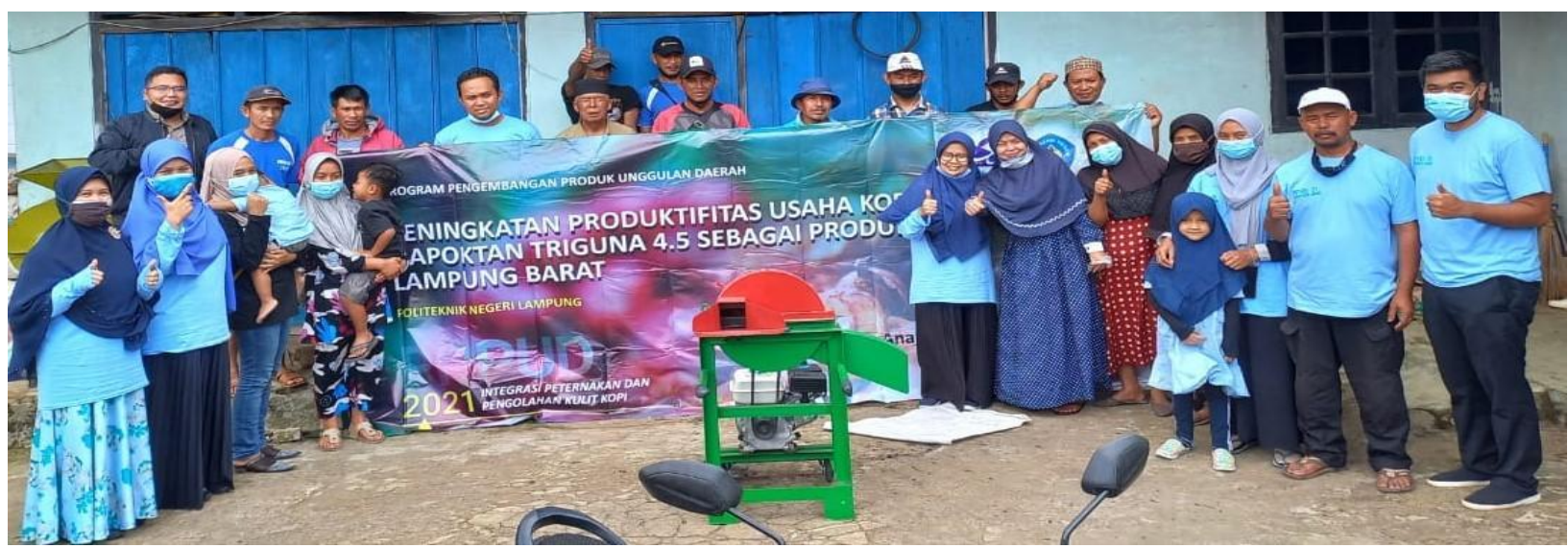

Gambar 3

Serah terima mesin pencacah untuk pendampingan pengolahan limbah kulit kopi menjadi pakan ternak.

Selama pelaksanaan pendampingan pengolahan limbah kulit kopi menjadi pakan ternak petani mendapatkan penyuluhan dalam pengelolaan limbah kotoran kambing dari kandang kambing 


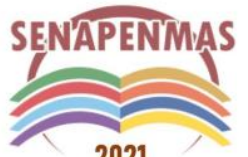

2021
Seminar Nasional Hasil Penelitian dan Pengabdian Kepada Masyarakat 2021

Pengembangan Ekonomi Bangsa Melalui Inovasi Digital Hasil Penelitian dan Pengabdian Kepada Masyarakat Jakarta, 21 Oktober 2021

dengan desain kandang kambing sehat. Perkandangan merupakan salah satu tata laksana pemeliharaan yang harus diperhatikan. Usaha peternakan kambing dapat berkembang secara optimal jika kandang yang menjadi tempat tinggal nyaman dan bersih (Bulan \& Subekti, 2018). Pada kegiatan PPPUD tim membuat kandang yang memiliki sanitasi yang baik terutama memahami struktur bangunan kandang. Pembuatan kandang bertujuan untuk pembesaran kambing, sehingga memperhatikan layout kandang kambing terutama penataan tempat pembuangan kotoran, desain kandang panggung, memiliki ventilasi dan atap tinggi, serta sekat kandang (Gambar 4).
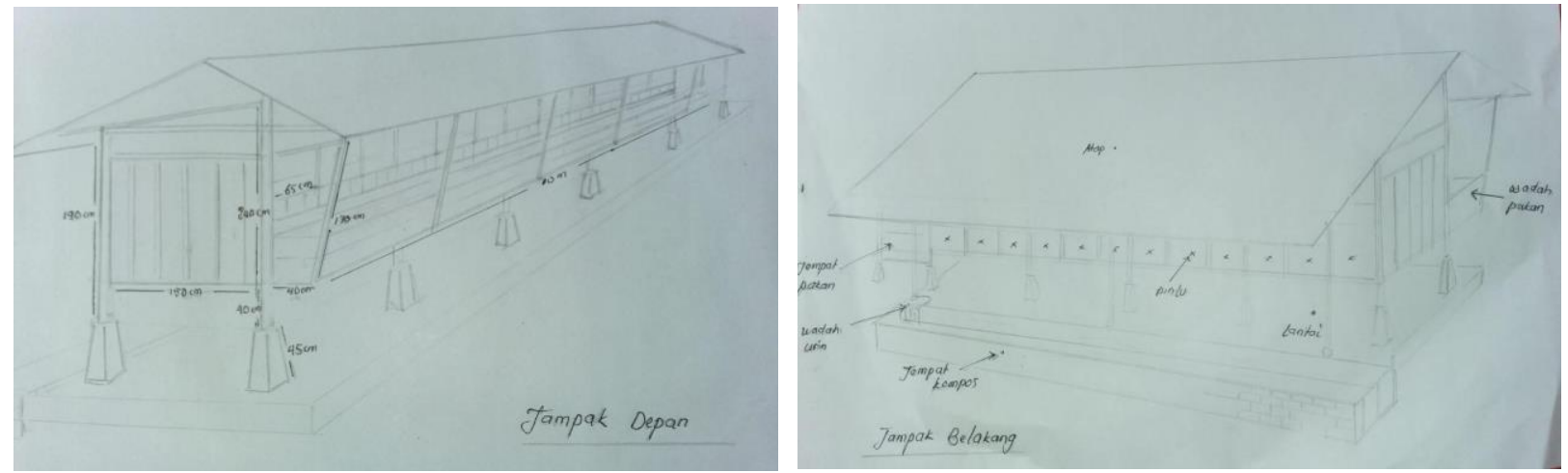

Gambar 4. Layout kandang kambing tampak depan dan belakang

Pada layout kandangg yang telah dibuat, lantai kandang harus dibuat berjarak agar kotoran dan urin langsung jatuh kebawah. Kandang didesain untuk pembesaran kambing sehingga bersifat individu yang disekat dengan ukuran badan kambing sehingga mudah dalam penanganan. Gambar 5 menunjukkan kandang untuk pembesaran kambing kacang.

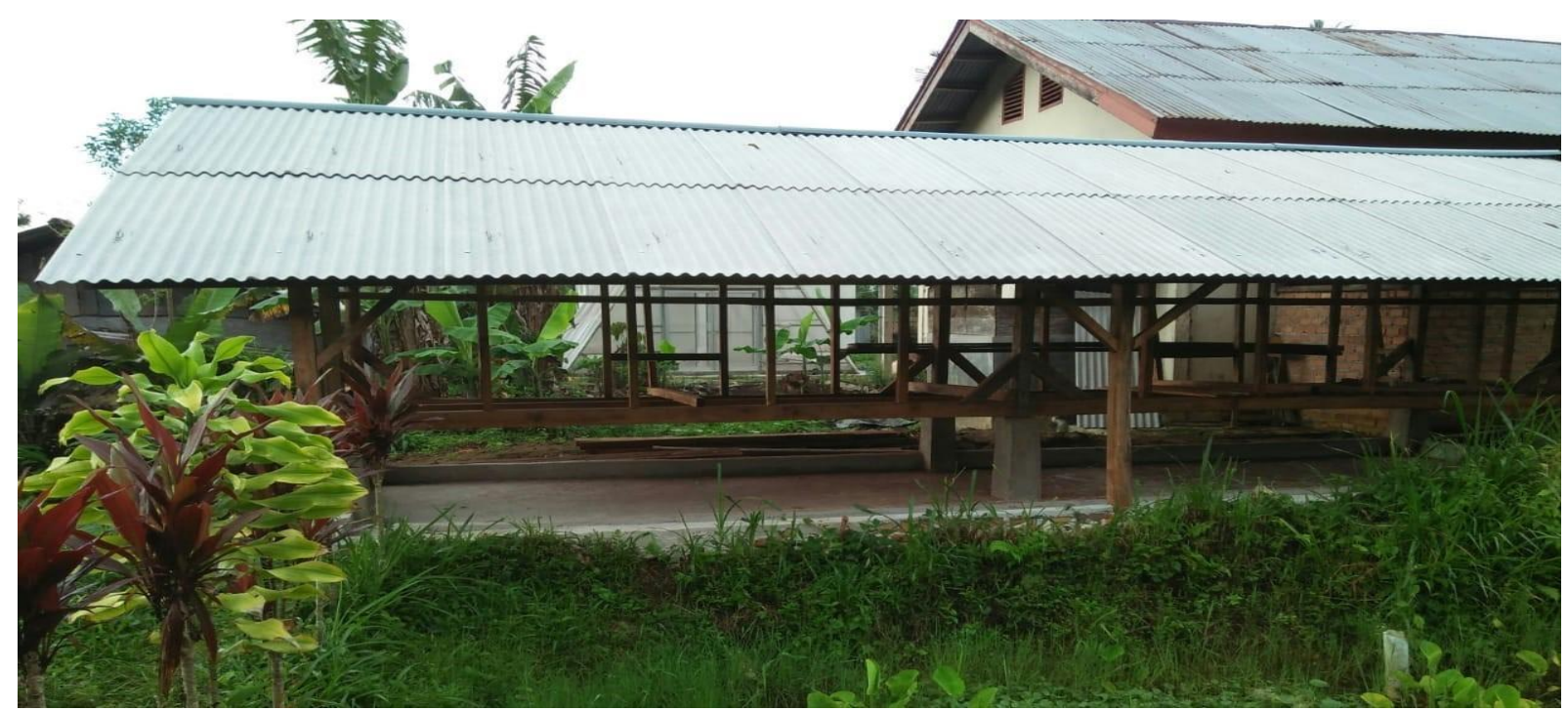

Gambar 5

Konsep kandang panggung yang dilengkapi dengan tempat penampungan kotoran dan urin kambing

Sistem pertanian terpadu dengan manajemen pengelolaan perkandangan dengan sanitasi yang baik dan sehat. Kesehatan kambing didukung dari asupan pakan yang memiliki kandungan nutrisi yang tinggi dari hasil fermentasi limbah kulit kopi. Secara ekonomi pendapatan petani 
kopi dapat ditingkatkan dengan integrasi pertanian terpadu antara peternakan kambing, limbah hasil olahan produksi kopi, dan budidaya kopi. Peternakan kambing dengan manajemen pengelolaan limbah yang dihasilkan dapat meningkatkan pendapatan dari penjualan pupuk kandang kotoran kambing dan mengefisienkan pengeluaran pembelian pupuk untuk budidaya kopi.

Hasil kegiatan akhir menunjukkan bahwa petani sangat antusias menerima transfer inovasi pelatihan pengolahan pakan ternak dari limbah kopi dan bantuan kandang untuk penggemukan kambing lokal dengan konsep kandang sehat. Kandang dilengkapi dengan tempat pembuangan kotoran dan urin kambing sehingga limbah tersebut dapat diolah menjadi pupuk kandang. Pupuk kandang dapat digunakan kembali untuk memenuhi unsur hara pada tanaman kopi sehingga menghasilkan buah kopi yang memiliki cita rasa yang baik dan kandungan antioksidan yang tingggi. Selain itu, pupuk kandang dapat dijual pada petani lain sehingga meningkatkan pendapatan Gapoktan. Bain et al., (2021) menyatakan bahwa peternak kambing Kendari memiliki semangat dalam pengolahan kambing menjadi pupuk kompos yang bernilai ekonomi.

\section{KESIMPULAN DAN SARAN}

Kegiatan Program Pengembangan Produk Unggulan Daerah memberikan transfer inovasi pemaanfaatan pengolahan limbah dan konsep kandang sehat. Kegiatan memberikan kontribusi (1) peningkatan pengetahuan dan keterampilan dalam memanfaatkan limbah kulit kopi dan bahan serat lainnya untuk pakan ternak, serta (2) peningkatan pengetahuan untuk mengelola kandang kambing dengan tempat pembuangan limbah kotoran sehingga dapat dimanfaatkan untuk pengolahan limbah menjadi pupuk kompos sehingga meningkatkan pendapatan anggota gapoktan.

\section{Ucapan Terima Kasih}

Penulis mengucapkan terimakasih kepada Kementrian Riset dan Teknologi/Badan Riset dan Inovasi Nasional Direktorat Riset dan Pengabdian Kepada Masyarakat dengan kontrak Nomor: 022/SP2H/PPMDRPM/2021.

\section{REFERENSI}

Analianasari, A., Kenali, E.W., Berliana, D. \& Yulia, M. 2021. Penguatan Kapasitas Produksi Kopi Robusta Premium Gapoktan Triguna 4.5. Qardhul Hasan, 7(1): 126-132.

Bain, A., Kurniawan, W., Has, H., Malesi, L., Syamsuddin, S., Aka, R., Isnaeni, P.D., Nurhayu, N. \& Daoed, D.M. 2021. Optimalisasi Usaha Peternakan Kambing Melalui Teknologi Pengolahan Limbah Peternakan untuk Meningkatkan Pendapatan Peternak Kambing di Kota Kendari Goat Farming Optimation Through Farm Waste Utilization Technology to Increase Goat Farmers Income in Kendar. Media Kontak Tani Ternak, 3(1): 21-26.

Bulan, D.S. \& Subekti, S. 2018. Proses Pembelajaran Sosial Perkandangan pada Peternak Kambing. Pembangunan Pertanian dan Peran Pendidikan Tinggi Agribisnis: Peluang dan Tantangan di Era Industri 4.0. hal.484-498.

Efendi, Z. \& Harta, L. 2013. Kandungan Nutrisi Hasil Fermentasi Kulit Kopi (Studi Kasus Desa Air Meles Bawah Kecamatan Curup Timur).

Hadija, H., Ikawati, I. \& Nirawati, N. 2016. Kajian Potensi Pengembangan Teknologi Sistem Integrasi Tanaman Jagung Dan Ternak Model Zero Waste Di Kabupaten Soppeng. Agrotan, 2(2): 68-84. Tersedia di http://ejournals.umma.ac.id/index.php/agrotan/article/view/9.

Linda, M., Rifaldy, M., Rachmad, R. \& Mustarin, A. 2018. Pemberdayaan Anak Putus Sekolah 


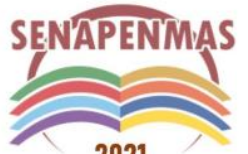

2021
Seminar Nasional Hasil Penelitian dan Pengabdian Kepada Masyarakat 2021

Pengembangan Ekonomi Bangsa Melalui Inovasi Digital Hasil Penelitian dan Pengabdian Kepada Masyarakat Jakarta, 21 Oktober 2021

Dalam Pemanfaatan Limbah Kulit Kopi Sebagai Pakan Ruminansia. Jurnal Pendidikan Teknologi Pertanian, 4(2): 16.

S, G., Yasa, R. \& Sugama, N. 2002. Hasil Pengkajian Pemanfaatan Limbah Perkebunan (Kakao dan Kopi) Untuk Pakan Ternak. Bali.

Saragih, E.W. 2020. Sistem Pertanian Terpadu Dengan Sistem Kandang Paddock Untuk Meningkatkan Pendapatan. Dinamisia: Jurnal Pengabdian Kepada Masyarakat, 4(1): 133-139.

Winarso, B. \& Basuno, E. 2013. Pengembangan Pola Integrasi Tanaman-Ternak Merupakan Bagian Upaya Mendukung Usaha Pembibitan Sapi Potong Dalam Negeri. Forum penelitian Agro Ekonomi, 31(2): 151. 
Seminar Nasional Hasil Penelitian dan Pengabdian Kepada Masyarakat 2021

Pengembangan Ekonomi Bangsa Melalui Inovasi Digital Hasil Penelitian dan

Pengabdian Kepada Masyarakat

Jakarta, 21 Oktober 2021

(halaman kosong) 